\title{
Synchronous Changes of Nitrogen and Carbon Isotopic Ratios and Nannoplankton Assemblage in Marine Sediments off Peru at 250 ka: A Role of Phytoplankton in Primary Ocean Productivity
}

\author{
Hidenao Hasegawa ${ }^{1}$, Itsuro Kita ${ }^{2}$, Shingo Tsukamoto ${ }^{2}$, Shun Chiyonobu ${ }^{3}$, Yoshihiro Kuwahara ${ }^{2}$ \\ ${ }^{1}$ Institute for Environmental Sciences, Aomori, Japan \\ ${ }^{2}$ Department of Environmental Changes, Faculty of Social and Cultural Studies, Kyushu University, Fukuoka, Japan \\ ${ }^{3}$ Research Institute of Innovative Technology for the Earth, Kyoto, Japan \\ Email: kita@scs.kyushu-u.ac.jp
}

Received February 28, 2013; revised March 28, 2013; accepted April 15, 2013

Copyright (C) 2013 Hidenao Hasegawa et al. This is an open access article distributed under the Creative Commons Attribution License, which permits unrestricted use, distribution, and reproduction in any medium, provided the original work is properly cited.

\begin{abstract}
We report the mechanism controlling changes of $\delta^{15} \mathrm{~N}_{\text {org }}$ and $\delta^{13} \mathrm{C}_{\text {org }}$ values of marine organic matter, based on the change of calcareous nannoplankton assemblage during the last 500,000 years in core samples from ODP Hole 846B off Peru in the equatorial Pacific Ocean. The $\delta^{15} \mathrm{~N}_{\text {org }}$ values fluctuate in a range from 2.1\%o to 6.7\%, giving an abrupt increase since about $250 \mathrm{ka}$ with the averages of $3.8 \%$ and $5.0 \%$ during the older and younger periods, respectively. The $\delta^{13} \mathrm{C}_{\text {org }}$ values change in a range from $-23.5 \%$ to $-20.1 \%$ in an inverse correlation with $\delta^{15} \mathrm{~N}_{\text {org }}$ values, describing an increase of average values at $250 \mathrm{ka}$ as well as those of $\delta^{15} \mathrm{~N}_{\text {org }}$ values. The total organic carbon content also shows averages of $0.6 \%$ and $0.3 \%$ during the younger and older periods, respectively. The numerical increase of deep dwelling species (Florisphaera profunda) of calcareous nannoplankton during the younger period in comparison with the older period indicates that these chemical and isotopic jumps synchronized with nannoplankton assemblage changes in marine sediments are caused by activity of deep dwellers in photic zone more stratified by an abrupt decline of trade wind strength on this sea area since about $250 \mathrm{ka}$. A study coupling $\delta^{15} \mathrm{~N}_{\text {org }}$ and $\delta^{13} \mathrm{C}_{\text {org }}$ values and nannoplankton assemblage can be a useful method for evaluating the extent of stratification of photic zone and the roles of surface and deep dwellers of phytoplankton in producing primary organic matter.
\end{abstract}

Keywords: Nannoplankton Assemblage; Nitrogen and Carbon Isotopes; Organic Matter; Biological Productivity; Sediment off Peru

\section{Introduction}

The stratification and its collapse of marine photic zone can be taken place by climatic change in strength of the wind on the sea giving the changes of nutrient content and temperature in it. The remarkable changes in such an oceanographic condition have been taken place in the equatorial upwelling zone of the Pacific Ocean. Chavez and Barber [1] reported that the equatorial sea area accounts for about $20 \%-60 \%$ of global biological productivity. The production of marine particles containing dead bodies of phytoplankton and organic matter produced by them in photic zone is an initial stage of circulation system of elements and their isotopes composing them through their production, dissolution and precipitation processes in the ocean $[2,3]$. Therefore, the structural change of photic zone acts the most important and basic role on biological productivity and marine chemistry.

Calcareous nannoplankton (coccolithophores) is one of phytoplankton and the most important primary producers in the oceans and has been used for discussing paleoclimate and paleoenvironment in addition to their reconstructions [4-7]. Calcareous nannoplankton can be both surface and deep dwelling species. Florisphaera profunda ( $F$. profunda) is a major deep dwelling species [8-12]. Based on core samples from Indian Ocean, Beaufort et al. [11] reported that the abundance of $F$. profunda in fossil assemblages can be used to monitor the depth of the nutricline for paleoproductivity study, because its relative abundance increases in stratified photic water where the upper photic zone is impoverished in nutrients and the nutricline is deep. Conversely, F. profunda decreases 
in relative abundance in stirred photic zone where wind stress induces a rise of the nutricline and an increase of primary production in the upper photic zone. According to them, in stirred photic zone, surface dwelling species is a producer of primary production. However, the relationships between productivities of surface and deep dwellers of phytoplankton and nitrogen and carbon isotopic ratios of organic matter by them in marine sediments have been seldom reported.

Hasegawa et al. [13] and Kita et al. [14] reported the first evidence that the absolute abundance of surface dwelling species of calcareous nannoplankton has changed in a positive correlation with nitrogen isotopic ratio $\left(\delta^{15} \mathrm{~N}_{\text {org }}\right)$ of organic matter during a period of about 300 ka to $1330 \mathrm{ka}$, using core samples made mainly of nannoplankton ooze from ODP Hole 1006A off Great Bahama Bank of the Caribbean Sea. This result suggests a possibility that primary productivity of marine organic matter and changes of its $\delta^{15} \mathrm{~N}_{\text {org }}$ and $\delta^{13} \mathrm{C}_{\text {org }}$ can be clarified in connection with nannoplankton assemblage changes by using their activity as representative one of phytoplankton.

Using the core samples during the last 500,000 years from ODP Hole 846B drilled in the sea area off Peru, Chiyonobu et al. [12] and Chiyonobu [15] reported that the numerical proportion of $F$. profunda to surface dwelling species deposited as microfossils increases during a younger period than $250 \mathrm{ka}$ in comparison with older one. Based on this result, they inferred that the photic zone of this sea area during the younger period has been stratified more than during the older period. By this reason, it is expected that the core samples from sea area off Peru recording the sudden environmental change at $250 \mathrm{ka}$ are useful for clarifying which of surface and deep dwelling species of phytoplankton plays as a producer of organic matter in photic zone and a controller of its isotopic behavior.

In this study, we aimed to clarify the roles of surface and deep dwelling species on their productivity of organic matter and controlling its nitrogen and carbon isotopic changes, using the same core samples from ODP Hole 846B drilled in sea area off Peru used by Chiyonobu et al. [12].

\section{Locality of ODP Hole 846B and Its Geological Setting}

Figure 1 shows the location $\left(3^{\circ} 5.7^{\prime} \mathrm{S}, 90^{\circ} 49.08^{\prime} \mathrm{W}\right)$ of ODP Hole 846B nestled in the Galapagos Islands in the eastern equatorial Pacific Ocean. This hole is reached at 422.4 meters below see floor (mbsf) at a depth of 3296 meters below sea surface [16]. These core samples are composed mainly of nannoplankton and foraminiferal ooze containing foraminifera. Cores of $0.27 \mathrm{mbsf}$ to 19.4 mbsf were used as samples of this study, and 197 sam-

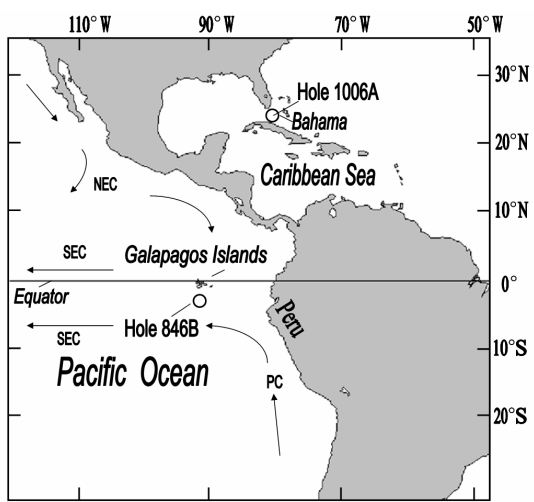

Figure 1. Location of ODP Hole 846B in the sea area off Peru. NEC: North equatorial current; SEC: South equatorial current; PC: Peru current.

ples were collected at approximately $10-\mathrm{cm}$ intervals. Chiyonobu [15] already reported the sedimentary ages (the present to $567 \mathrm{ka}$ ) of core samples used in this study, based on tuning a changing pattern of $\delta^{18} \mathrm{O}_{\text {benthic }}$ reported by Mix et al. [17] in comparison with $\delta^{18} \mathrm{O}_{\text {planktonic value }}$ of LR04 [18] in addition to reference points following index fossils of calcareous nannoplankton. The reference points of age determination were the first occurrence of Emiliania huxleyi (Lohmann) Hay and Mohler (0.25 Ma) (8.56 mbsf) and the last occurrence of Pseudoemiliania lacunosa (Kamptner) Gartner (0.41 Ma) (16.13 mbsf).

\section{Experimental Methods}

\subsection{Total Contents of Organic Carbon and Nitrogen and Their Isotopic Ratios}

Sediment samples from $0.5 \mathrm{~g}$ to $1.0 \mathrm{~g}$ were dissolved by $\mathrm{HCl}(1 \mathrm{~N})$ to remove carbonate in them. The remains $(10-$ $30 \mathrm{mg}$ ) wrapped up in a tin foil were set into the elemental analyzer (ThermoQuest, NC2500) with $\mathrm{Cr}_{2} \mathrm{O}_{3}$ and silvered cobaltous-cobaltic oxide mixed with $\mathrm{Ag}\left(\mathrm{Co}_{3} \mathrm{O}_{4} /\right.$ $\mathrm{Ag})$ and metallic cupper, at heated at $1000^{\circ} \mathrm{C}$ and $650^{\circ} \mathrm{C}$, respectively, to measure their total organic carbon (TOC) and total nitrogen (TN). Subsequently, using $\mathrm{He}$ as carrier gas, the $\mathrm{CO}_{2}$ and $\mathrm{N}_{2}$ gases were introduced into a mass spectrometer (ThermoQuest, MAT 252) to measure their isotopic ratios.

Their carbon and nitrogen isotopic ratios are represented as follows.

$$
\delta(\%)=\left[\left(\mathrm{R}_{\text {sample }} / \mathrm{R}_{\text {standard }}\right)-1\right] \times 10^{3}
$$

where $R$ is ${ }^{15} \mathrm{~N} /{ }^{14} \mathrm{~N}$ or ${ }^{13} \mathrm{C} /{ }^{12} \mathrm{C}$ ratios, and air and VPDB were used as standard materials for $\delta^{15} \mathrm{~N}(\%)$ and $\delta^{13} \mathrm{C}$ (\%) measurements, respectively.

\subsection{Measurements of Absolute Abundance of Calcareous Nannoplankton in Core Samples}

The absolute abundance of calcareous nannoplankton 
was measured by an ordinary method. A powdered sample $(0.04 \mathrm{~g})$ was suspended in water $\left(50 \mathrm{~cm}^{3}\right)$. A portion $\left(0.5 \mathrm{~cm}^{3}\right)$ of the solution was dried up on the cover glass $(18 \mathrm{~mm} \times 18 \mathrm{~mm})$. The samples were mounted on a microslide using Norland optical adhesive. The number of coccoliths in an area of $18 \mathrm{~mm} \times 20 \mu \mathrm{m}$ was counted under the crossed polarizing microscope at a magnification of $\times 1500$ (Olympus, BX-50). A total of 200 specimens of nannoplankton excluding Florisphaera profunda were counted at random to determine their relative frequencies. The total number of nannoplankton that occurred in a straight transect were counted to calculate the absolute abundance contained in $1 \mathrm{~g}$ (specimens/g). The number of $F$. profunda compared with 200 other nannoplanktons was counted separately [12].

\section{Results}

\subsection{Relationship between $\delta^{15} \mathrm{~N}_{\text {org }}$ and $\delta^{13} \mathrm{C}_{\text {org }}$ Values of Organic Matter}

Figure 2 shows the relationship between $\delta^{15} \mathrm{~N}_{\text {org }}$ and $\delta^{13} \mathrm{C}_{\text {org }}$ values of organic matter during a period from the present to $576 \mathrm{ka}$, using their raw data and smoothing curves. The $\delta^{15} \mathrm{~N}_{\text {org }}$ value changes in a range from $2.1 \%$ to $6.7 \%$, showing an abrupt increase since about $250 \mathrm{ka}$. $\delta^{13} \mathrm{C}_{\text {org }}$ value ranges from $-23.5 \%$ to $-20.1 \%$ o higher clearly than terrestrial one, showing an abrupt jump reaching $-20.2 \%$ at $250 \mathrm{ka}$ as well as $\delta^{15} \mathrm{~N}_{\text {org }}$. In addition, during the whole period from the present to $576 \mathrm{ka}$, $\delta^{13} \mathrm{C}_{\text {org }}$ value changes in an inverse correlation with $\delta^{15} \mathrm{~N}_{\text {org }}$.

\subsection{Relationships between Calcareous Nannoplankton Assemblage, TOC Content, and $\delta^{15} \mathbf{N}_{\text {org }}$ and $\delta^{13} \mathrm{C}_{\text {org }}$ Values}

The absolute abundance of surface dwelling species of nannoplankton changes in a range from about $5 \times 10^{8}$ specimens $/ g$ to $350 \times 10^{8}$ specimens $/ g$, describing a clear drop at about $280 \mathrm{ka}$ (Figure 3(a)). Subsequently, their abundance decreases gradually, reaching a mean value of $50 \times 10^{8}$ specimens/g since $100 \mathrm{ka}$ (Figure 3(a)). Their

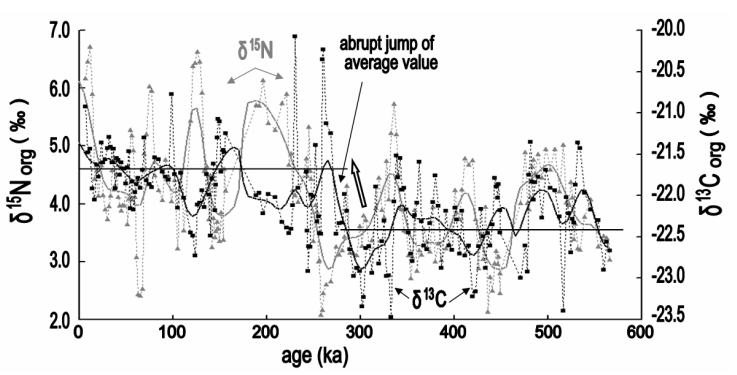

Figure 2. Relationship between $\delta^{15} \mathrm{~N}_{\text {org }}$ and $\delta^{13} \mathrm{C}_{\text {org }}$ values in core samples of ODP Hole 846B. Arrow indicates an abrupt jump of average value.

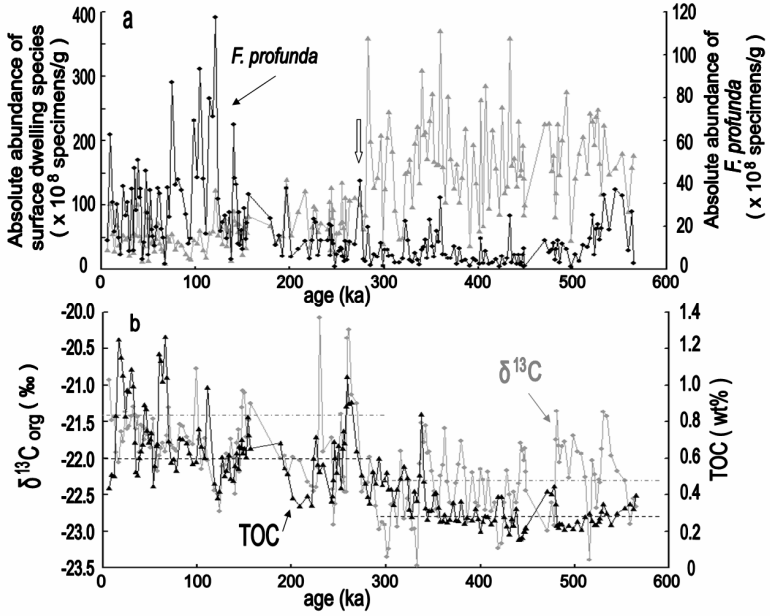

Figure 3. Relationships between absolute abundances of surface dwelling species and $F$. profunda of calcareous nannoplankton (a) and $\delta^{13} \mathrm{C}_{\text {org }}$ and total organic carbon (TOC) content (b), in core samples of ODP Hole 846B. Arrow indicates an abrupt decrease of absolute abundance of surface dwelling species.

mean values during the younger and older periods than $280 \mathrm{ka}$ are $50 \times 10^{8}$ specimens/g and $150 \times 10^{8}$ specimens/g, respectively (Figure 3(a)), keeping $80 \times 10^{8}$ specimens/g during a transition period from $280 \mathrm{ka}$ to $200 \mathrm{ka}$.

The absolute abundance of $F$. profunda changes in a relatively low range from about $1 \times 10^{8}$ specimens/g to $120 \times 10^{8}$ specimens/g in comparison with the abundance of surface dwelling species. However, its mean abundance during the younger and older periods than $280 \mathrm{ka}$ gives $38 \times 10^{8}$ specimens $/ g$ and $10 \times 10^{8}$ specimens $/ g$, respectively, keeping $15 \times 10^{8}$ specimens/g during a period of transition from $280 \mathrm{ka}$ to $200 \mathrm{ka}$. That is, the downward and rising curves of abundances of surface and deep dwellers since $280 \mathrm{ka}$ cross at about $250 \mathrm{ka}$ (Figure 3(a)).

TOC content also changes in a range from $0.16 \mathrm{wt} \%$ to $1.1 \mathrm{wt} \%$, giving a jump at about $260 \mathrm{ka}$ (Figure 3(b)). Its mean values of the older and younger periods are 0.3 $\mathrm{wt} \%$ and $0.6 \mathrm{wt} \%$, respectively. This parameter also describes a rising curve with $\delta^{13} \mathrm{C}_{\text {org }}$ value from about 250 ka. However, they seem to change inversely in small scale (Figure 3(b)). The $\delta^{15} \mathrm{~N}_{\text {org }}$ changes in positive correlation with the abundance of surface dwelling species during the older period (Figure 4(a)), correlating inversely with the abundance of $F$. profunda (Figure 4(b)). However, during the younger period since $250 \mathrm{ka}$, the changing pattern of $\delta^{15} \mathrm{~N}_{\text {org }}$ corresponds to that of abundance of $F$. profunda (Figure 4(a)). A rising curve of $\delta^{15} \mathrm{~N}_{\text {org }}$ over a wide range from $2 \%$ to $6 \%$ exists during a transition period from 280 to $200 \mathrm{ka}$ which the downward and rising curves of abundances of surface and deep dwellers since 280 ka cross (Figure 4(b)). 


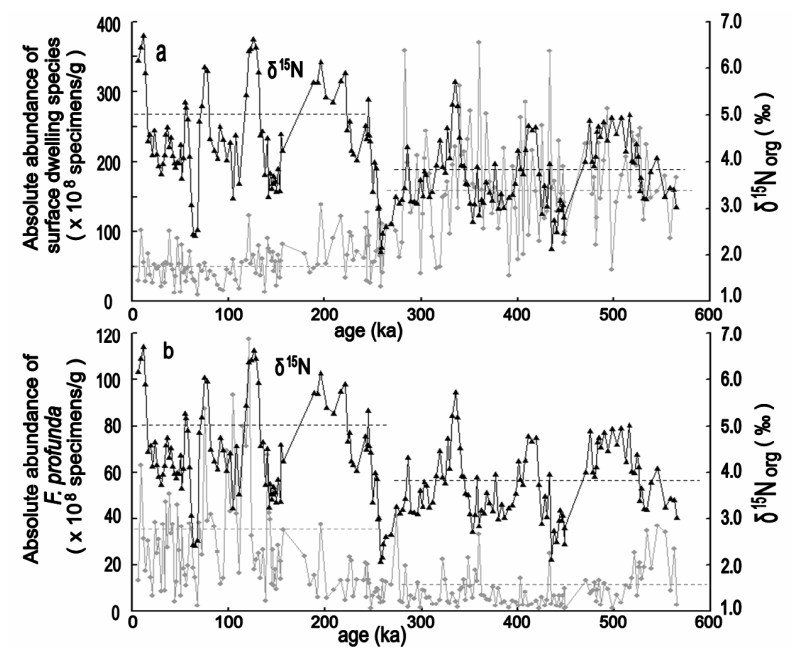

Figure 4. Relationships between $\delta^{15} \mathbf{N}_{\text {org }}$ and absolute abundances of surface dwelling species of calcareous nannoplankton (a) and $F$. profunda (b).

\section{Discussion}

\subsection{Changes of $\delta^{15} \mathrm{~N}_{\text {org }}$ and $\delta^{13} \mathrm{C}_{\text {org }}$ Values and TOC Content Relating to Biological Activity}

The $\delta^{13} \mathrm{C}_{\text {org }}$ value changes in a range from $-23.5 \%$ to $-20.1 \%$, showing the inverse correlation with $\delta^{15} \mathrm{~N}_{\text {org }}$ value (Figure 3(b)). The former values are in a range higher clearly than those from terrestrial values [19], showing that organic matter in these core samples was produced in marine. Therefore, it is likely that there is a biological mechanism showing inverse correlation between $\delta^{15} \mathrm{~N}_{\text {org }}$ and $\delta^{13} \mathrm{C}_{\text {org }}$ values of organic matter produced by phytoplankton.

It is worthy of notice that the average values of $\delta^{15} \mathrm{~N}_{\text {org }}$ and $\delta^{13} \mathrm{C}_{\text {org }}$ values are different between the younger period than about $250 \mathrm{ka}$ and the older period (Figure 2). During a short period from $280 \mathrm{ka}$ to $250 \mathrm{ka}$, the extreme decrease and increase of $\delta^{15} \mathrm{~N}_{\text {org }}$ and $\delta^{13} \mathrm{C}_{\text {org }}$ occur, respectively, corresponding to a drop of abundance of surface dwelling species during a short period from $300 \mathrm{ka}$ to $250 \mathrm{ka}$ (Figure 3(a)). During the subsequent period from $250 \mathrm{ka}$ to $200 \mathrm{ka}, \delta^{15} \mathrm{~N}_{\text {org }}$ describes a jump over the wide range which is accompanied by the drop of $\delta^{13} \mathrm{C}_{\text {org }}$. As a result, $\delta^{15} \mathrm{~N}_{\text {org }}$ forms the large inverse curves with $\delta^{13} \mathrm{C}_{\text {org }}$ at about $250 \mathrm{ka}$ in this transition period of $280 \mathrm{ka}$ to $200 \mathrm{ka}$ (Figure 2). TOC content also describes a large peak corresponding to that of $\delta^{13} \mathrm{C}_{\text {org }}$ during a period from $280 \mathrm{ka}$ to $250 \mathrm{ka}$ (Figure 3(b)).

The absolute abundance of surface dwelling species becomes extremely low during the younger period than $250 \mathrm{ka}$ in comparison with that during the older period, and the abundance of $F$. profunda becomes reverse, crossing their rising and downward curves during the transition period from 280 ka to $200 \mathrm{ka}$ (Figure 3(a)). In addition, the abundance of warm water species of nanno- plankton also shows an abrupt increase since about 250 ka [12]. Based on an abrupt change of calcareous nannoplankton assemblage, Chiyonobu et al. [12] inferred that the photic zone of this sea area during the younger period has been stratified more than during the older period. In other words, upwelling level of cold deeper water to photic water during a younger period is lower than that during the older period. In this study, it was clarified that TOC content as well as abundance of $F$. profunda describes a rising curve, crossing with downward curve of that of surface dwelling species at $250 \mathrm{ka}$ (Figure 3(a)).

Judging from concurrent changes of $\delta^{15} \mathrm{~N}_{\text {org }}$ and $\delta^{13} \mathrm{C}_{\text {org }}$ values and TOC content connecting with change of nannoplankton assemblage, the deep dwelling species of phytoplankton containing $F$. profunda are responsible for their changes. That is, not surface dwelling species but deep dwelling species of phytoplankton produce the organic matter in the sea area off Peru. Beaufort [10] reported, however, that the increase of organic carbon content (TOC) corresponds to that of absolute abundance of surface dwelling species (placoliths) during a period from the present to $260 \mathrm{ka}$ in the equatorial Indian Ocean. That is, surface dwellers produce the organic matter in the Indian Ocean in this period. The difference between our study and Beaufort [10] means that producer of organic matter may be different in various marine environments. In either case, it is likely that concurrent jumps of $\delta^{15} \mathrm{~N}_{\text {org }}$ and $\delta^{13} \mathrm{C}_{\text {org }}$ values and TOC content at the boundary of about $250 \mathrm{ka}$ can be connected to the difference in the extent of stratification of photic zone of sea area off Peru.

\subsection{Jumping Mechanism of $\delta^{15} \mathrm{~N}_{\text {org }}$ and $\delta^{13} \mathrm{C}_{\text {org }}$ of Organic Matter at 250 ka}

\subsection{1. $\delta^{15} \mathrm{~N}_{\text {org }}$}

It is well known that nitrate in marine water feeds phytoplankton. In this consumption process of nitrate by phytoplankton, ${ }^{14} \mathrm{NO}_{3}^{-}$can be consumed preferentially in comparison with ${ }^{15} \mathrm{NO}_{3}^{-}$; this consumption results in the production of organic matter with a $\delta^{15} \mathrm{~N}_{\text {org }}$ lower than that of nitrate in photic water $[14,20,21]$. The nitrate content depth profile in the photic water must be controlled by the mixing between photic water and deeper water, because nitrate levels span a large gradient in the photic zone $[22,23]$. In other words, the higher the amount of nitrate in photic water by the mixing between photic and deeper waters, the higher the $\delta^{15} \mathrm{~N}_{\text {org }}$ value of organic matter produced by phytoplankton propagated in eutrophic photic water becomes, depositing a higher number of its fossils.

Figure 5(a) describes schematic diagram of jumps of $\delta^{15} \mathrm{~N}_{\text {org }}$ and $\delta^{13} \mathrm{C}_{\text {org }}$ at about $250 \mathrm{ka}$ and their inverse changes in a small scale during the whole period of about 500,000 years. Figure 5(b) shows the roles of surface 


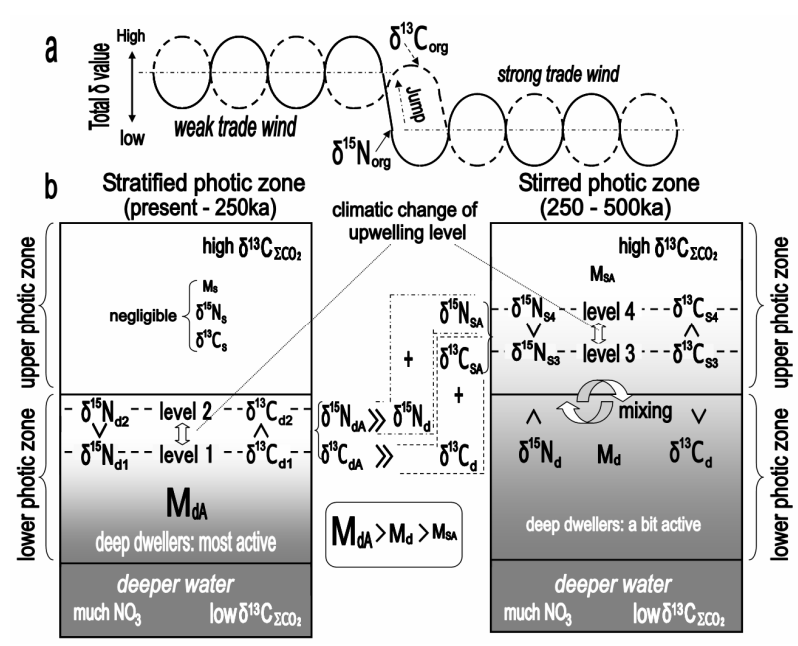

Figure 5. (a) Schematic diagram of a jump of $\delta^{15} \mathbf{N}_{\text {org }}$ and $\delta^{13} \mathrm{C}_{\text {org }}$ at about $250 \mathrm{ka}$ and their inverse changes during the whole period of 500,000 years. (b) Changing mechanism of biological productivity of organic matter and its $\delta^{15} N_{\text {org }}$ and $\delta^{13} \mathrm{C}_{\text {org }}$ taken place by changes of upwelling levels in the lower and upper photic zones. In the stratified period: $\mathbf{M}_{\mathrm{S}}$, $\delta^{15} \mathrm{~N}_{\mathrm{S}}$ and $\delta^{13} \mathrm{C}_{\mathrm{S}}$ mean the amount of organic matter produced by surface dwellers and its $\delta^{15} \mathrm{~N}$ and $\delta^{13} \mathrm{C} . \delta^{15} \mathrm{~N}_{\mathrm{d} 1}$ and $\delta^{13} \mathrm{C}_{\mathrm{d} 1}$ and $\delta^{15} \mathrm{~N}_{\mathrm{d} 2}$ and $\delta^{13} \mathrm{C}_{\mathrm{d} 2}$ are of organic matter produced by deep dwellers at the upwelling levels 1 and 2 , respectively, and $\mathrm{M}_{\mathrm{dA}}, \delta^{15} \mathrm{~N}_{\mathrm{dA}}$ and $\delta^{13} \mathrm{C}_{\mathrm{dA}}$ are an average amount of organic matter produced by deep dwellers and its average $\delta^{15} \mathrm{~N}$ and $\delta^{13} \mathrm{C}$. In the stirred period: $\delta^{15} \mathrm{~N}_{\mathrm{S} 3}$ and $\delta^{13} \mathrm{C}_{\mathrm{S} 3}$ and $\delta^{15} \mathrm{~N}_{\mathrm{S} 4}$ and $\delta^{13} \mathrm{C}_{\mathrm{S} 4}$ are of organic matter produced by surface dwellers at levels 3 and 4 , respectively. $\mathrm{M}_{\mathrm{SA}}, \delta^{15} \mathrm{~N}_{\mathrm{SA}}$ and $\delta^{13} \mathrm{C}_{\mathrm{SA}}$ are an average amount of organic matter produced by surface dwellers at levels 3 and 4 , and its average $\delta^{15} \mathrm{~N}$ and $\delta^{13} \mathrm{C} . \mathrm{M}_{\mathrm{d}}, \delta^{15} \mathrm{~N}_{\mathrm{d}}$ and $\delta^{13} \mathrm{C}_{\mathrm{d}}$ are the amount of organic matter produced by deep dweller and its $\delta^{15} \mathrm{~N}$ and $\delta^{13} \mathrm{C}$.

and deep dwellers in production of marine organic matter and change of its $\delta^{15} \mathrm{~N}_{\text {org }}$ and $\delta^{13} \mathrm{C}_{\text {org }}$ values in stratified and stirred photic zones. Upwelling levels of deeper water with much nitrate into photic zone are described by levels 1 and 2 in lower photic zone during younger period than $250 \mathrm{ka}$ and by levels 3 and 4 reaching upper photic zone during the older one. The changes of upwelling levels 1 and 2 and levels 3 and 4 are responsible for their inverse changes of $\delta^{15} \mathrm{~N}_{\text {org }}$ and $\delta^{13} \mathrm{C}_{\text {org }}$ values during the younger and older periods, respectively. In this section, a jump of $\delta^{15} \mathrm{~N}_{\text {org }}$ between younger and older periods is discussed, using an average of the amount of organic matter $\left(\mathrm{M}_{\mathrm{dA}}\right)$ produced in levels 1 and 2 and its $\delta^{15} \mathrm{~N}_{\mathrm{dA}}$ and that $\left(\mathrm{M}_{\mathrm{SA}}\right)$ in levels 3 and 4 and its $\delta^{15} \mathrm{~N}_{\mathrm{SA}}$ (Figure 5(b)).

Under the stratified photic zone during the younger period, the number of $F$. profunda is enhanced in lower photic zone, reaching the same number as that of surface dwellers (Figure 3(a)). Much amount of organic matter $\left(\mathrm{M}_{\mathrm{dA}}\right)$ with high $\delta^{15} \mathrm{~N}_{\mathrm{dA}}$ must be produced in eutrophic lower photic zone with much nitrate content by deep dwellers. Conversely, negligible amount $\left(\mathrm{M}_{\mathrm{s}}\right)$ of organic matter with extremely low $\delta^{15} \mathrm{~N}_{\mathrm{s}}$ can be produced by surface dwellers in the oligotrophic upper photic zone with little nitrate content, because of its low consumption rate by them. That is, $\delta^{15} \mathrm{~N}_{\mathrm{s}}$ must make weak contribution to total $\delta^{15} \mathrm{~N}_{\text {org }}$ of organic matter produced in whole photic zone. As a result, $\mathrm{M}_{\mathrm{dA}}$ produced by deep dwellers is responsible for the greater part of total organic matter (Figure 3(b)) and high $\delta^{15} \mathrm{~N}_{\text {org }}$ in the younger period and its total $\delta^{15} \mathrm{~N}_{\text {org }}$ can be controlled by high $\delta^{15} \mathrm{~N}_{\mathrm{dA}}$ of organic matter produced by deep dwellers (Figure 4).

In the stirred photic zone during the older period than about 250 ka under the relatively active upwelling condition, the upwelling level of deeper water can be considered to reach the upper photic zone with a small change of its level as shown by levels 3 and 4 (Figure 5(b)). Under this stirred condition, the number of $F$. profunda decreases up to about $10 \%$ in comparison with that in stratified lower photic zone (Figure 4(b)), though the lower photic zone is more eutrophic than that in the younger period. The numerically reduced deep dwellers must produce a little amount of organic matter $\left(\mathrm{M}_{\mathrm{d}}\right)$ with lower $\delta^{15} \mathrm{~N}_{\mathrm{d}}$ value in comparison with $\mathrm{M}_{\mathrm{dA}}$ in stratified photic zone (Figures 3(b) and 4), because of a drop in their consumption of nitrate. Surface dwellers can produce a little amount of organic matter $\left(\mathrm{M}_{\mathrm{SA}}\right)$ in comparison with $\mathrm{M}_{\mathrm{d}}$ produced by deep dwellers $\left(\mathrm{M}_{\mathrm{d}}>\mathrm{M}_{\mathrm{SA}}\right)$ (Figure 5(b)), because nitrate content in the upper photic zone is significantly lower than that in the lower photic zone, though surface dwellers increase the number by only four in average (Figure 4(a)). Therefore, total amount of organic matter produced in whole photic zone in the older period also can be controlled mainly by activity of deep dwellers (Figure 5(b)). On the other hand, $\delta^{15} \mathrm{~N}_{\mathrm{SA}}$ of organic matter $\left(\mathrm{M}_{\mathrm{SA}}\right)$ produced by surface dwellers is still lower than $\delta^{15} \mathrm{~N}_{\mathrm{d}}$ (Figure 5(b)), because nitrate content in surface photic zone is significantly lower than that in the lower photic zone and its consumption by surface dwellers is lower. That is, $\delta^{15} \mathrm{~N}_{\mathrm{dA}}, \delta^{15} \mathrm{~N}_{\mathrm{d}}$ and $\delta^{15} \mathrm{~N}_{\mathrm{SA}}$ become low in order as well as $\mathrm{M}_{\mathrm{dA}}, \mathrm{M}_{\mathrm{d}}$ and $\mathrm{M}_{\mathrm{SA}}$ (Figure $5(b))$. As these results, the whole amount $\left(\mathrm{M}_{\mathrm{dA}}\right)$ of organic matter and its $\delta^{15} \mathrm{~N}_{\mathrm{dA}}$ produced in the stratified photic zone can increase in comparison with those $\left(\mathrm{M}_{\mathrm{d}}+\mathrm{M}_{\mathrm{SA}}\right.$ and $\delta^{15} \mathrm{~N}_{\mathrm{d}}+\delta^{15} \mathrm{~N}_{\mathrm{SA}}$ ) in stirred one at 250 ka during the transition period from $280 \mathrm{ka}$ to $200 \mathrm{ka}$ (Figures 3 and 5(b)).

\subsection{2. $\delta^{13} \mathrm{C}_{\text {org }}$}

The $\delta^{13} \mathrm{C}_{\text {org }}$ value can be affected by isotopic effect as well as $\delta^{15} \mathrm{~N}$ value. Hayes [24] reviewed factors controlling $\delta^{13} \mathrm{C}$ value of synthesized organic compound, with regard to modes of carbon assimilation by phytoplankton, such as 1) the $\delta^{13} \mathrm{C}$ value of carbon source, 2) isotope 
effects associated with assimilation of carbon by the producing organism, 3) isotope effects associated with metabolism and biosynthesis, and 4) cellular carbon budgets at each branch point. According to him, for an autotroph, the carbon source will be environmental carbon dioxide or bicarbonate (total carbonic acid, $\Sigma \mathrm{CO}_{2}$ ) and isotope effects associated with assimilation of carbon are great importance in autotrophic organism. By the reason, the change of $\delta^{13} \mathrm{C}_{\text {org }}$ value may be explained in a first approximation by the difference in the $\delta^{13} \mathrm{C}_{\Sigma \mathrm{CO}_{2}}$ values of total carbonic acid $\left(\Sigma \mathrm{CO}_{2}\right)$ between photic and deeper waters which is the carbon source.

In surface water, its $\delta^{13} \mathrm{C}$ value (about $+2 \%$ ) under the isotopic equilibrium with atmospheric $\mathrm{CO}_{2}$ is higher than that (about $-0.5 \%$ ) in deeper water [25], and the content of total carbonic acid $(\sim 2000 \mu \mathrm{mol} / \mathrm{l})$ in surface water is similar to that $(2300-2400 \mu \mathrm{mol} / \mathrm{l})$ of deeper water $[22,23]$. The content of total carbonic acid is enough high for the production of organic matter, and the mixing of photic and deeper waters can yield only a weak decrease in the content of total carbonic acid in photic water. As the result, it is likely that both the $\delta^{13} \mathrm{C}_{\mathrm{\Sigma CO}}$ value in photic water and $\delta^{13} \mathrm{C}_{\text {org }}$ value of organic matter produced by phytoplankton can be affected weakly during the preferential consumption process. The changes in $\delta^{13} \mathrm{C}_{\mathrm{org}}$ value of organic matter produced by phytoplankton can be considered to be controlled mainly by change of $\delta^{13} \mathrm{C}_{\mathrm{\Sigma CO}}$ value in photic water.

In the stratified lower photic zone, the carbonic matter with low $\delta^{13} \mathrm{C}$ value decreased by addition of deeper water to the lower photic water can be consumed for producing much organic matter $\left(\mathrm{M}_{\mathrm{d}}\right)$ with low $\delta^{13} \mathrm{C}_{\mathrm{dA}}$ value by active deep dwellers (Figure 5(b)). In the upper photic zone, $\delta^{13} \mathrm{C}_{\mathrm{S}}$ of $\mathrm{M}_{\mathrm{S}}$ produced by surface dwellers can be negligible as well as its $\delta^{15} \mathrm{~N}_{\mathrm{s}}$. On the other hand, in stirred lower photic zone, numerically reduced deep dwellers can produce organic matter $\left(\mathrm{M}_{\mathrm{d}}\right)$ with lower $\delta^{13} \mathrm{C}_{\mathrm{d}}$ in comparison with $\delta^{13} \mathrm{C}_{\mathrm{dA}}$ in the stratified lower photic zone, because this zone is filled with deeper water with low $\delta^{13} \mathrm{C}_{\Sigma \mathrm{CO}_{2}}$. Under this condition, surface dwellers produce organic matter $\left(\mathrm{M}_{\mathrm{SA}}\right)$ with $\delta^{13} \mathrm{C}_{\mathrm{SA}}$ higher than $\delta^{13} \mathrm{C}_{\mathrm{d}}$ in the lower photc zone, because the mixing of deep water to the upper photic zone must be weak in comparison with that to the lower photic zone, resulting that $\delta^{13} \mathrm{C}_{\Sigma \mathrm{CO}_{2}}$ of the upper photic water is higher than that of lower photic water. Therefore, the amount $\left(\mathrm{M}_{\mathrm{SA}}\right)$ of organic matter with higher $\delta^{13} \mathrm{C}_{\mathrm{SA}}$ is so small that it cannot negate the decrease of $\delta^{13} \mathrm{C}_{\mathrm{d}}$ of organic matter $\left(\mathrm{M}_{\mathrm{d}}\right)$ produced by deep dwellers $\left(\mathrm{M}_{\mathrm{d}}>\mathrm{M}_{\mathrm{SA}}\right)$ (Figure 5(b)), judging from an observation that high TOC content corresponds to the increase in the number of not surface dwellers but deep dwellers (Figure 3). As the result, total $\delta^{13} \mathrm{C}_{\text {org }}$ of total organic matter produced during the younger period since $250 \mathrm{ka}$ with stratified photic zone can become higher than that during the older period with stirred photic zone (Figure 3(b)), describing concurrent jumps with $\delta^{15} \mathrm{~N}_{\text {org }}$ and TOC content.

\subsubsection{Mechanism of Inverse Changes of $\delta^{15} \mathrm{~N}_{\text {org }}$ and $\delta^{13} \mathrm{C}_{\text {org }}$ and Its Implication}

Inverse changes of $\delta^{15} \mathrm{~N}_{\text {org }}$ and $\delta^{13} \mathrm{C}_{\text {org }}$ of organic matter in a small scale observed during both the younger and older periods can be explained by the following mechanism. In the upwelling level 2 during the stratified younger period, the organic matter generated by deep dweller has higher $\delta^{15} \mathrm{~N}_{\mathrm{d} 2}$ and lower $\delta^{13} \mathrm{C}_{\mathrm{d} 2}$ in comparison with $\delta^{15} \mathrm{~N}_{\mathrm{dA}}$ and $\delta^{13} \mathrm{C}_{\mathrm{dA}}$, because of increase of nitrate content and decrease of $\delta^{13} \mathrm{C}_{\mathrm{\Sigma CO}}$ in whole lower photic water. Conversely, in the level 1 which nitrate content is lower and $\delta^{13} \mathrm{C}_{\Sigma \mathrm{CO}_{2}}$ is higher, deep dweller can generate organic matter with lower $\delta^{15} \mathrm{~N}_{\mathrm{d} 1}$ and higher $\delta^{13} \mathrm{C}_{\mathrm{d} 1}$ (Figure 5(a)).

In eutrophic lower photic zone during the stirred older period, $\delta^{15} \mathrm{~N}_{\mathrm{d}}$ of $\mathrm{M}_{\mathrm{d}}$ produced by deep dweller can be considered to have only weak contribution on total $\delta^{15} \mathrm{~N}_{\text {org }}$, because the change in the number of surface dweller corresponds to that of $\delta^{15} \mathrm{~N}_{\text {org }}$ during the older photic zone (Figure 4(a)). In the high upwelling level 4, organic matter generated by surface dweller has higher $\delta^{15} \mathrm{~N}_{\mathrm{S} 4}$ and lower $\delta^{13} \mathrm{C}_{\mathrm{S} 4}$ in comparison with $\delta^{15} \mathrm{~N}_{\mathrm{SA}}$ and $\delta^{13} \mathrm{C}_{\mathrm{SA}}$, because of increase of nitrate content and decrease of $\delta^{13} \mathrm{C}_{\Sigma \mathrm{CO}_{2}}$ in the whole upper photic water. Conversely, in the low level 3 with lower nitrate content and higher $\delta^{13} \mathrm{C}_{\Sigma \mathrm{CO}_{2}}$, the $\delta^{15} \mathrm{~N}_{\mathrm{S} 3}$ and $\delta^{13} \mathrm{C}_{\mathrm{S} 3}$ can become lower and higher, respectively, than those in the level 4.

Both the concurrent jumps of $\delta^{15} \mathrm{~N}_{\text {org }}$ and $\delta^{13} \mathrm{C}_{\text {org }}$ values and TOC content at about $250 \mathrm{ka}$ and their inverse changes in a small scale through the whole period of 500,000 years can be explained consistently, based on the differences in the extent of photic zone stratification and changes in productivities of surface and deep dwelling species of nannoplankton in it. That is, the behavior of surface and deep dwellers of nannoplankton can be used as representative of those of phytoplankton. The global climatic events at approximately $300 \mathrm{ka}$ in various climatic subsystems also have been reported by many researchers [26-32].

Saino and Hattori [2] and Altabet et al. [3] have reported a possibility that $\delta^{15} \mathrm{~N}_{\text {org }}$ values of particles formed in photic zone has been changed through the decomposition and dissolving processes suffered during their deposition. The changes of our $\delta^{15} \mathrm{~N}_{\text {org }}$ and $\delta^{13} \mathrm{C}_{\text {org }}$ values in core samples of sea area off Peru, however, link to those of TOC content and nannoplankton assemblage. This result suggests the existence of some mechanism to protect organic matter produced by phytoplankton and its fossil from their degeneration such as formation of big particles and wrapping them in the fecal pellets of pre- 
dators that are fed on phytoplankton (e.g., zooplankton and fishes), as reported by Honjo [33]. That is, it is likely that marine sediments are formed not from small particle which can be degenerated easily but from such a big particle which can deposit in a short time on the see floor. Therefore, the marine sediment can be useful to clarify the oceanographic condition acting the most important and basic role on biological productivity and marine chemistry, by a biogeochemical study coupling $\delta^{15} \mathrm{~N}_{\text {org }}$ and $\delta^{13} \mathrm{C}_{\text {org }}$ values, nannoplankton assemblage and others.

\section{Conclusion}

$\delta^{15} \mathrm{~N}_{\text {org }}$ and $\delta^{13} \mathrm{C}_{\text {org }}$ of organic matter and TOC content in core samples (ODP Hole 846B) during about 500,000 years off Peru in the East Pacific Ocean show concurrent jumps of their average values at about $250 \mathrm{ka}$, describing inverse changes of $\delta^{15} \mathrm{~N}_{\text {org }}$ and $\delta^{13} \mathrm{C}_{\text {org }}$ during the whole period. The numerical increase of $F$. profunda (deep dwelling species) of calcareous nannoplankton during the younger period indicates that the average values of $\delta^{15} \mathrm{~N}_{\text {org }}, \delta^{13} \mathrm{C}_{\text {org }}$ and TOC content become higher in the photic zone more stratified by an abrupt decline of the trade wind strength on the sea off Peru since $250 \mathrm{ka}$. These synchronous jumps are occurred mainly by activity of deep dwellers of phytoplankton such as F. profunda in lower photic water enhanced by a drop of upwelling level from the upper photic zone to lower one. The inverse changes of $\delta^{15} \mathrm{~N}_{\text {org }}$ and $\delta^{13} \mathrm{C}_{\text {org }}$ reveal the change of upwelling level of deeper water into photic water in a small scale during each of younger and older periods. Therefore, a biogeochemical study coupling $\delta^{15} \mathrm{~N}_{\text {org }}$ and $\delta^{13} \mathrm{C}_{\text {org }}$ values and nannoplankton assemblage gives undoubted evidences that the marine sediment can be useful to clarify the extent of stratification of photic zone and the roles of surface and deep dwellers of phytoplankton in producing primary organic matter.

\section{Acknowledgements}

In this study, the core samples from ODP Hole 846B drilled off Peru in the East Pacific Ocean was used.

\section{REFERENCES}

[1] F. P. Chavez and R. T. Barber, "An Estimate of New Production in the Equatorial Pacific," Deep-Sea Research, Vol. 34, No. 7, 1987, pp. 1229-1243. doi:10.1016/0198-0149(87)90073-2

[2] T. Saino and A. Hattori, “15 N natural Abundance in Oceanic Suspended Particulate Matter," Nature, Vol. 283, 1980, pp. 752-754. doi:10.1038/283752a0

[3] A. Altabet, R. Francols, W. Murray and L. Prell, "Climate-Related Variations in Denitrification in the Arabian Sea from Sediment ${ }^{15} \mathrm{~N} /{ }^{14} \mathrm{~N}$ Ratios," Nature, Vol. 373, 1995, pp. 506-509. doi:10.1038/373506a0
[4] B. U. Haq, "Biogeographic History of Miocene Calcareous Nannoplankton and Paleoceanography of the Atlantic Ocean," Micropaleontology, Vol. 26, No. 4, 1980, pp. 414-443. doi: $10.2307 / 1485353$

[5] T. Sato and K. Kameo, "Pliocene to Quaternary Calcareous Nannofossil Biostratigraphy of the Arctic Ocean, with Reference to Late Pliocene Glaciation," In: J. Thiede, A. M. Myhre, J. V. Firth, G. L. Johnson and W. F. Ruddiman, Eds., Proceedings of the Ocean Drilling Program, Scientific Results, Vol. 151, 1996, pp. 39-59.

[6] J. Bollmann, "Morphology and Biogeography of Gephyrocapsa coccoliths in Holocene Sediments," Marine Micropaleontology, Vol. 29, 1997, pp. 319-350. doi:10.1016/S0377-8398(96)00028-X

[7] T. Sato, S. Yuguchi, T. Takayama and K. Kameo, "Drastic Change in the Geographical Distribution of the ColdWater Nannofossil Coccolithus pelagicus (Wallich) Schiller at 2.74 Ma in the Late Pliocene, with Special Reference to Glaciation in the Arctic Ocean," Marine Micropaleontology, Vol. 52, 2004, pp. 181-193. doi:10.1016/j.marmicro.2004.05.003

[8] H. Okada and S. Honjo, "The Distribution of Oceanic Coccolithophorids in the Pacific," Deep-Sea Research, Vol. 20, 1973, pp. 355-374.

[9] B. Molfino and A. McIntyre, "Precessional Forcing of Nutricline Dynamics in the Equatorial Atlantic," Science, Vol. 249, 1990, pp. 766-769. doi:10.1126/science. 249.4970 .766

[10] L. Beaufort, "Dynamics of the Monsoon in the Equatorial Indian Ocean over the Last 260,000 years," Quaternary International, Vol. 31, 1996, pp. 13-18. doi:10.1016/1040-6182(95)00017-D

[11] L. Beaufort, Y. Lancelot, P. Camberlin, O. Cayre, E. Vincent, F. Bassinot and L. Labeyrie, "Insolation Cycles as a Major Control of Equatorial Indian Ocean Primary Production," Science, Vol. 278, 1997, pp. 1451-1454. doi:10.1126/science.278.5342.1451

[12] S. Chiyonobu, T. Sato, R. Narikiyo and M. Yamasaki, "Floral Changes in Calcareous Nannofossils and Their Paleoceanographic Significance in the Equatorial Pacific Ocean during the Last 500,000 Years," Island Arc, Vol. 15,2006 , pp. 476-482. doi:10.1111/j.1440-1738.2006.00543.x

[13] H. Hasegawa, I. Kita and T. Sato, "Correlation between Nitrogen Isotopic Ratios and Productivity of Calcareous Nannoplankton of the Quaternary Sediments off Bahama Bank of the Caribbean Sea," Goldschmidt Conference, Kurashiki, Kurasiki Sayou University, Goldschmidt, 7-12 September 2003, p. A137.

[14] I. Kita, H. Hasegawa, T. Sato, T. Hayashi and M. Kojima, "Correlation between Nitrogen Isotopic Ratios and Productivity of Calcareous Nannoplankton: Evidence for the Biological Consumption of Nitrate Controlling Nitrogen Isotopic Fluctuation," Fossils, No. 86, 2009, pp. 59-66.

[15] S. Chiyonobu, "Upwelling Strength and Water Mass Structure Changes in the Equatorial Pacific Ocean during the Last 550 kyr as Recorded by Calcareous Nannofossil Assemblages," Fossils, No. 86, 2009, pp. 34-44.

[16] Shipboard Scientific Party, "Site 846," In: L. Mayer, N. 
Pisias, T. Janecek, et al., Eds., Proceeding of the Ocean Drilling Program, Initial, Reports, Vol. 138, 1992, pp. 265-333. doi:10.2973/odp.proc.ir.138.111.1992

[17] A. C. Mix, J. Le and N. J. Shackelton, "Benthic Foraminiferal Stable Isotope Stratigraphy of Site 846: 0-1.8 Ma. In: N. G. Pisias, L. A. Mayer, T. R. Janecek, A. PalmerJulson and T. H. van Andel, Eds., Proceedings of the Ocean Drilling Program, Scientific Results, Vol. 138, 1995, pp. 839-854. doi:10.2973/odp.proc.sr.138.160.1995

[18] L. E. Lisiecki and M. E. Raymo, "A Pliocene-Pleistocene Stack of 57 Globally Distributed Benthic $\delta^{18}$ O Records," Paleoceanography, Vol. 20, 2005, Article ID: PA1003. doi:10.1029/2004PA001071

[19] K. E. Peters, R. E. Sweeney and I. R. Kaplan, "Correlation of Carbon and Nitrogen Stable Isotope Ratios in Sedimentary Organic Matter," Limnology and Oceanography, Vol. 23, No. 4, 1978, pp. 598-604. doi:10.4319/10.1978.23.4.0598

[20] T. Nakatsuka, N. Harada, E. Matsumoto, N. Handa, T. Oba, M. Ikehara, H. Matsuoka and K. Kimoto, "GlacialInterglacial Migration of an Upwelling Field in the Western Equatorial Pacific Recorded by Sediment ${ }^{15} \mathrm{~N} /{ }^{14} \mathrm{~N}$," Geophysical Research Letters, Vol. 22, No. 18, 1995, pp. 2525-2528. doi:10.1029/95GL02544

[21] T. Nakatsuka, N. Handa, N. Harada, T. Sugimoto and S. Imaizumi, "Origin and Decomposition of Sinking Particulate Organic Matter in the Deep Water Column Inferred from the Vertical Distributions of Its $\delta^{15} \mathrm{~N}, \delta^{13} \mathrm{C}$ and $\delta^{14}$ C," Deep-Sea Research Part I, Vol. 44, No. 12, 1997, pp. 1957-1979. doi:10.1016/S0967-0637(97)00051-4

[22] P. M. Kroopnick, "The Distribution of ${ }^{13} \mathrm{C}$ of $\Sigma \mathrm{CO}_{2}$ in the World Oceans," Deep-Sea Research, Vol. 32, No. 1, 1985, pp. 57-84. doi:10.1016/0198-0149(85)90017-2

[23] K.-K. Liu and I. R. Kaplan, "The Eastern Tropical Pacific as a Source of ${ }^{15} \mathrm{~N}$-Enriched Nitrate in Seawater off Southern California," Limnology and Oceanography, Vol. 34, No. 5, 1989, pp. 820-830. doi:10.4319/10.1989.34.5.0820

[24] M. J. Hayes, "Factors Controlling ${ }^{13} \mathrm{C}$ Contents of Sedimentary Organic Compounds: Principles and Evidence," Marine Geology, Vol. 113, 1993, pp. 111-125. doi:10.1016/0025-3227(93)90153-M
[25] P. D. Naidu and N. Niitsuma, "Atypical $\delta^{13} \mathrm{C}$ Signature in Globigerina bulloides at the ODP Site 723A (Arabian Sea): Implications of Environmental Changes Caused by Upwelling," Marine Micropaleontology, Vol. 53, 2004, pp. 1-10. doi:10.1016/i.marmicro.2004.01.005

[26] T. R. Janecek and D. K. Rea, "Quaternary Fluctuations in the Northern Hemisphere Trade Winds and Westerlies," Quaternary Research, Vol. 24, 1985, pp. 150-163. doi:10.1016/0033-5894(85)90002-X

[27] J. H. F. Jansen, A. Kuijpers and S. R. Troelstra, "A MidBrunhes Climatic Event: Long-Term Changes in Global Atmosphere and Ocean Circulation," Science, Vol. 232, 1986, pp. 619-622. doi:10.1126/science.232.4750.619

[28] S. A. Hovan, D. K. Rea and N. G. Pisias, "Late Pleistocene Continental Climate and Oceanic Variability Recorded in Northwest Pacific Sediments," Paleoceanography, Vol. 6, No. 3, 1991, pp. 349-370. doi:10.1029/91PA00559

[29] A. A. Prokopenko, D. F. Williams, M. I. Kuzmin, E. B. Karabanov, G. K. Khursevich and J. A. Peck, "Muted Climate Variations in Continental Siberia during the MidPleistocene Epoch," Nature, Vol. 418, 2002, pp. 65-68. doi:10.1038/nature00886

[30] Q. Hao and Z. Guo, "Spatial Variations of Magnetic Susceptibility of Chinese Loess for the Last 600 kyr: Implications for Monsoon Evolution," Journal of Geophysical Research, Vol. 110, 2005, Article ID: B12101. doi:10.1029/2005JB003765

[31] Y. Suganuma, T. Yamazaki and T. Kanamatsu, "South Asian Monsoon Variability during the Past 800 kyr Revealed by Rock Magnetic Proxies," Quaternary Science Reviews, Vol. 28, 2009, pp. 926-938. doi:10.1016/i.quascirev.2008.12.014

[32] S. Chiyonobu, Y. Mori and M. Oda, "Reconstruction of Paleoceanographic Conditions in the Northwestern Pacific Ocean over the Last $500 \mathrm{kyr}$ based on Calcareous Nannofossil and Planktic Foraminiferal Assemblages," Marine Micropaleontology, Vol. 96-97, 2012, pp. 29-37. doi:10.1016/j.marmicro.2012.07.002

[33] S. Honjo, "Coccoliths: Production, Transportation and Sedimentation," Marine Micropaleontology, Vol. 1, 1976, pp. 65-79. doi:10.1016/0377-8398(76)90005-0 